\title{
Time-activity budgets and behaviour of the Amazilia hummingbird, Amazilia amazilia (Apodiformes: Trochilidae) in an urban environment
}

\author{
M. Calviño-Cancela \\ Departamento de Ecología y Biología Animal, Universidad de Vigo, EUET Forestal, Campus Universitario, E-36005, \\ Pontevedra, España; maria@uvigo.es
}

Received 15-V-2003. Corrected 12-VIII-2005. Accepted 17-III-2006.

\begin{abstract}
This study deals with the time-activity budgets of Amazilia amazilia, a territorial hummingbird, and its preferences for different flower species and perches in the gardens of Lima (Peru) in September 2001. A. amazilia spent an important part of its time resting on perches (ca. 80\%) and only $15.5 \%$ for foraging, devoted essentially to flower visitation and only $0.3 \%$ for hunting and drinking water. Territorial defence accounted for $2 \%$ of total time, mostly against Coereba flaveola, an introduced nectarivorous species that seem to be an important competitor of $A$. amazilia. Flower use is not directly related to flower abundance $\left(\chi_{9}^{2}=1546, \mathrm{p}<0.0001\right)$, with Justicia brandegeana and red-flowered Salvia splendens being selected and Impatiens balsamina being rejected. The large amount of time spent on the perches makes them an important element of the habitat. The perches selected are typically on trees, close to the flowers visited, and in a low vertical and middle horizontal position, surrounded by low foliage density, probably to minimize heat loss. Rev. Biol. Trop. 54 (3): 873-878. Epub 2006 Sept. 29.
\end{abstract}

Key words: time-activity budgets, urban gardens, habitat use, Amazilia amazilia.

The amount of time each individual devotes to certain behaviours can provide insights into the requirements and constrains acting upon it, and is influenced by its condition, social status and the environmental conditions of the area (Paulus 1988, Adams et al. 2000).

Hummingbirds have very high-energy demands. On one hand, they are among the smallest homeotherms, and consequently they are among the animals with highest known mass-specific basal metabolic rates during inactivity (Lasiewski and Dawson 1967). Furthermore, they have exceptionally high metabolic rates during activity as they forage by energetically costly hovering. These particularities can impose certain constrains for the time-activity budgets.

The Amazilia Hummingbird, Amazilia a. amazilia Lesson, is a medium-sized troquilid (length: ca. 8-11 cm, weight: 4-7 g) that inhabits arid and semiarid habitats of the tropical Pacific lowlands and adjacent subtropical Andean slopes, eg: edges of deserts, scrub and dry forests, of Ecuador and Peru (Koepche 1964, Weller 2000). It is a territorial and nectarivorous bird and territories are defended by individuals or pairs against conspecifics or other nectarivorous species (González 1998, M.C.C., pers. obs.). It is very common in the parks and gardens of the cities (Koepcke 1964, M.C.C., pers. obs.) and is familiar with human presence, so it can be observed very closely. Like most of hummingbirds, it is diurnal and has sedentary habits, so its movements are restricted to relatively small areas, and therefore it keeps in view of the observer for long periods of time. For these reasons, it is particularly suitable for observational studies.

It is the most common hummingbird in the city of Lima, which shows its ability to adapt 
to human-altered environments. Bird conservation in urban environments requires ecological information that can be applied to city planning and designing (Maeda 1998). Considering the urban environment as a new ecological system rather than a degraded environment, two different groups of birds inhabiting them can be distinguished: (1) the omnivorous species with generalist habits that get easily adapted to the abundant food resources available in the urban areas (eg garbage), and (2) non-generalist species that find in the urban environment the resources they normally exploit in their natural habitat (Clergeau et al. 1998). This is the case of the hummingbirds, that find in the gardens and parks of the city true "green islands" that provide the flowers to feed them.

In this paper the time Amazilia hummingbird allocates to its different activities, the frequency of its visits to different species of flowers and the characteristics of the perches it used is studied, with the objective of providing some information about the ecology and behaviour of this scarcely studied bird in an urban environment.

\section{MATERIALS AND METHODS}

The study was carried out in the botanical gardens of the Museum of Natural History and the Faculty of Medicine, in Lima (Peru).

To estimate the time-activity budgets the activities of at least nine individuals used as focal subjects were observed and timed, for periods of 2 to $5 \mathrm{~h}$. Total observation time was $714 \mathrm{~min}(\mathrm{ca} .20 \mathrm{~h})$, in nine different days in September 2001. The activities were classified in the following categories:

1. Resting on a perch: time spent sitting on a perch. No distinction was made between time sitting quietly and time spent preening, looking around or emitting any sound.

2. Flower visits: time spent visiting the flowers, including time flying among flowers inside the same patch.
3. Hunting: time spent catching small insects.

4. Chasing: time spent in flights towards an intruder, persecutions, aggressions, or flights around the intruder to try to force it away from the territory.

5. Being chased: time spent avoiding an aggression or escaping from the persecution of an aggressor of the same species or other territorial species.

6. Movements: time spent moving among perches or between perches and patches of flowers or other resources. Small movements among flowers or leaves inside patches are not included.

7. Drinking: the preening activity after having a bath is not included in this category, although the bird probably also takes in water with its tongue from the wet feathers.

8. Bathing: time spent bathing, often using puddles where water remains after irrigation.

For Salvia splendens Sello ex Roem and Schult, the speed of flower visitation was measured by dividing the total time spent in a foraging bout by the number of flowers visited, therefore it also includes the time spent flying among flowers in the same inflorescence or among close inflorescences. These measurements were carried out in 18 visits to this species.

Flower preferences were analyzed with a Chi-square test $\left(\chi^{2}\right)$ test to determine whether the frequencies of flower use differed from those expected on the basis of flower abundance: flowers used more than expected according to their abundance are being preferred while those less visited than expected are being avoided. Flower use was measured as time spent visiting each species and abundance by counting the number of opened flowers.

To describe the perches only those used repeatedly were included. The following characteristics were considered (Remsen and Robinson 1990):

a) Vertical position, described by a.1) height above ground, a.2) total height of the plant 
elected to perch. These two heights are visual estimates by the same observer for all the perches, a.3) relative position in the tree canopy: low, middle, high or in the top of the tree canopy.

b) Horizontal position: inner, middle or outer.

c) Foliage density: A qualitative scale was used from zero to five of increasing foliage density within a $1 \mathrm{~m}$ radius around the bird: 0 : no vegetation; 1 : very low vegetation density (95-99\% of all light passes through that $1 \mathrm{~m}$ radius imaginary sphere surrounding the bird); 2: low density, $75-95 \%$ of light passes; 3: moderate density, 25-75\% of light passes; 4: high density, only $5-25 \%$ of light passes; 5 : extremely dense, 0 to $5 \%$ of the light passes.

d) Branch angle: horizontal, vertical or diagonal.

\section{RESULTS}

A. amazilia spent the most of its time resting on perches $(79.5 \%, \mathrm{~N}=714 \mathrm{~min})$ (Table 1$)$. Foraging took $15.5 \%$ of time (flower visiting accounted for $14.9 \%$ of total time, being the second most important activity). The other activities together accounted for less than $7 \%$, and none of them reached 3\%. Flower visits (activity 2) were short, (17.1 $\pm 1.25 \mathrm{~s}, \mathrm{n}=164)$

\section{TABLE 1}

Time-activity budgets of Amazilia amazilia show the proportion of time spent in different activities

\begin{tabular}{lc}
\multicolumn{1}{l}{ Activity } & Proportion of time \\
Resting & 0.795 \\
Flower visits & 0.149 \\
Defence & 0.021 \\
Hunting & 0.003 \\
Attacked & 0.006 \\
Displacements & 0.020 \\
Drinking & 0.003 \\
Bathing & 0.004 \\
Total (min) & 714.1
\end{tabular}
one minute on average $(65.3 \pm 9.75 \mathrm{~s}, \mathrm{n}=241)$. A. amazilia visited $0.6 \pm 0.14$ flowers of $S$. splendens per second on average; therefore the visit to a flower takes ca. $1.7 \mathrm{~s}$, including the time needed to fly between flowers of the same inflorescence or close inflorescences.

Although flowers were the most important food resource for $A$. amazilia, they were not the only one. The birds spent on average $0.3 \%$ of time catching small insects and another $0.3 \%$ drinking water. Two different behaviours to catch insects were observed: 1) hovering at the leaves or inflorescences picking repeatedly on their surface and 2) short flights from perches to catch the insect and return to the perch (this behaviour, used by many birds to catch prey in flight, has been referred to by different names: flycath, sally, or hawk, see Remsen and Robinson 1990 and references therein). Different behaviours were also observed to drink water: (1) hovering at the leaves to pick the little drops that remain in their surfaces after irrigation, (2) hovering at the jet of water of the irrigation systems moving the tongue outside and inside the bill repeatedly, (3) preening, taking water from the wet feathers with the tongue after having baths in small puddles left after watering.

Territorial defence comprised $2.1 \%$ of the total time, including defence against conspecifics and individuals of other species. Of this time, $15.7 \%$ was spent in defence against other Amazilia hummingbirds and 84.3\% against Bananaquits (Coereba flaveola L., Embericidae). Time spent being attacked accounted for $0.5 \%$ of the total time, $60.2 \%$ of which was spent being attacked by other Amazilia hummingbirds and the other $39.8 \%$ by Bananaquits.

The red flowers of $S$. splendens were the most visited flowers, followed by the flowers of Justicia brandegeana Wass. and L. B. Sm.; the other flower species received only a small portion of the visits (Table 2). Flower use differed from the expected on the basis of flower abundance $\left(\chi_{9}^{2}=1546, \mathrm{p}<0.0001\right)$, with the flowers of $J$. brandegeana, S. splendens and, 
TABLE 2

Flower use and availability, Percentage of time spent feeding on each species and number of opened flowers available

Plant species

$$
\% \text { of total time }
$$$$
\begin{aligned}
& \mathrm{N}^{\circ} \text { opened } \\
& \text { flowers }
\end{aligned}
$$

Salvia splendens (red)

$$
57.9
$$$$
2262
$$

Salvia splendens (purple)

Justicia brandegeana

Aloe vera

Aloe barbadensis

Sanchezia peruviana

5

0.5

Impatiens balsamina

0.3

\section{6}

684

112

10

Euphorbia milii

to a lesser degree, Aloe barbadensis Mill being selected positively and the flowers of Impatiens balsamina L. and, to a lesser degree, Aloe vera (L.) Webb and Berth being avoided.

The perches used by $A$. amazilia were usually close to the patches of flowers visited. Height above ground was $4.6 \pm 1.2 \mathrm{~m}$ (range 1 to $8 \mathrm{~m}, \mathrm{n}=15)$, and the total height of the plants selected $8 \pm 2.1 \mathrm{~m}$ (range 1-16 m, $\mathrm{n}=$ 15). The distance between the bird and the top of the plant was $3.4 \pm 0.9 \mathrm{~m}$ (range $0-8 \mathrm{~m}, \mathrm{n}=$ 15). Thirteen of the 15 perches were located on trees and the rest on Opuntia sp. and Aloe sp. On the trees, the vertical position in the canopy was low in $85 \%$ of the perches $(\mathrm{N}=13)$ and middle in $15 \%$, with no cases in the other categories. The horizontal position in the canopy was middle in $62 \%(\mathrm{~N}=13)$ of perches, outer in $23 \%$ and inner in $15 \%$. The branch angle was horizontal in all the perches. The foliage density around the bird was usually low (53\% of perches, $\mathrm{N}=15$ ) or very low (20\%), and moderated in $27 \%$ of the perches. The vegetation coverage around the bird was ca. $21.6 \pm 5.8 \%$.

\section{DISCUSSION}

The Amazilia hummingbirds observed spent most of their time resting on perches, and only a small proportion foraging in the flowers and other activities. The values obtained in this study are in agreement with those of other studies carried out with other hummingbirds (Wolf and Hainsworth 1971, Ewald and Carpenter 1978). Although time spent visiting the flowers was relatively low, they do it at a very high speed, being able to visit a high amount of flowers in a short time. The way they forage on flowers, hovering instead of perching, allows them a high efficiency in flower visitation, with more than 30 flowers visited per minute, but is very expensive in terms of energy expenditure (Hainswoth and Wolf 1978). MacArthur and Pianka (1966) proposed that natural selection would favour foragers that maximise their net food intake per unit foraging time. Animals adopting this strategy are termed time minimizers (Schoener 1971). The fact that they forage in such short time and spent most of the time on the perches may suggest that they are time minimizers, nevertheless Karasov et al. (1986) suggest that this time could be required for crop emptying (ie food handling), so they may be energy maximizers that ingest energy as fast as their digestive processes allows.

As they spend a significant amount of time perching, perch selection became an important issue. They usually perched at relatively low height above ground, being close to the feeding flowers but out of the reach of terrestrial predators. Vegetation density is usually low in the perches they selected, which could provide little protection against flying predators but could be related with energy saving by reducing heat loss, since open sites are less shady. Although resting requires much less energy than visiting the flowers, energy expenditure for this activity could be significant considering their small size and the amount of time spent perched. Heat loss increases as the environmental temperature decreases; therefore, selection of hotter perches could save an important amount of energy.

Together with nectar, they also caught small insects and drank water. Their hunting activity suggests that the amino acids provided by the nectar are not enough to satisfy their needs. Some studies on hummingbirds' diets 
have indicated the presence of arthropods in variety and quantity (eg Henderson 1927). Small insects could also be captured while visiting the flowers, since flowers are also a good habitat for those animals (Wheeler 1980). On the other hand, the observation of these birds drinking water is remarkable since their diets are considered to contain an excess of water due to the high water content of nectar (McWhorter and Martínez del Rio 1999). In fact, the most visited species, S. splendens, produce dilute nectar (Sánchez et al. 2002), but it seems to be not enough to meet their requirements.

Territory defence comprised relatively a short time, nevertheless it was only considered defence when birds pursue or disturb intruders in the territory and not the continuous delivering of calls related with territorial defence. The interactions with Bananaquits are remarkable, both defence and attack. This is an introduced species in Lima that was reported for the first time in 1995 (Guillén and Barrio 1995) that became very abundant (González 1998). It is also a nectarivorous species that has been observed visiting flowers of $S$. splendens, $J$. brandeaga and A. vera (M.C.C., pers. obs.), but not as specialized in nectar feeding as hummingbirds (González 1998). To take the nectar, it pierces the corolla, acting usually as a nectar robber (Sazima and Sazima 1999). It is highly territorial and the agonistic behaviour with Amazilia hummingbirds has been reported previously (González 1998). Its body size is bigger than that of the Amazilia, making it difficult for the Amazilia to get these intruders away from the territory, while in the interactions against other Amazilia individuals the expulsion is immediate. This together with the abundance of Bananaquits made Amazilia hummingbirds spend more time involved in aggressions against them than against individuals of its own species, suggesting that Bananaquits are important competitors.

S. splendens was the most abundant and visited flower, and was positively selected by the hummingbirds. This species produces copious nectar with a secretion rate of c. 300 mg sugar per flower $\mathrm{h}^{-1}$ (Corbet et al. 2001). The flowers visited by the hummingbirds have in general tubular corollas of purple, red, pink, orange or yellow colour suggesting their adaptation for hummingbird pollination. $J$. brandegeana has a white and inconspicuous corolla but surrounded by numerous reddish bracts that probably function as attractors for the hummingbirds. The cyathia of Euphorbia milii Desmoul. are also inconspicuous but their broad, scarlet bracts together with copious and easily accessible nectar make this plant attractive to a wide range of pollinators including hummingbirds, a variety of insects, and even lizards (Font and Ferrer 1995). The flowers of I. balsamina have a slightly curved nectar spur protruding down from the back. Moths and butterflies can reach the nectar and are the primary pollinators of the genus but the thinness of the tube makes it difficult for the hummingbirds to reach the nectar, which may explain the low visitation rate to this species. The shape of the flowers of this two species, with no tubular corollas, make more difficult for the hummingbirds the contact with the stamens and stigma, thus hummingbirds probably act more as nectar robbers than as pollinators. With the only exception of Sanchezia peruviana (Ness) Rusby, all the species visited by the hummingbirds are very commonly used for gardening. The flower preferences shown by this species together with the characteristics of perches selected should be taken into account in garden designing in order to favour the presence of these birds.

\section{ACKNOWLEDGMENTS}

I am very grateful to Letty Salinas, César Arana and César Cordova, from the Faculty of Biology, Joel Rojas, their students, and the staff of the Agency of Cooperation for their kindness and assistance during my stage in the UNMSM, Lima. 


\section{RESUMEN}

Se estudió la distribución del tiempo en las actividades de Amazilia amazilia, un colibrí territorial, y sus preferencias por diferentes flores y perchas en los jardines de Lima (Perú), en septiembre de 2001. A. amazilia pasa una parte importante de su tiempo descansando en las perchas (ca. $80 \%$ ) y sólo un $15.5 \%$ alimentándose, dedicado fundamentalmente a visitar flores y sólo un $0.3 \%$ a cazar y a beber agua. La defensa del territorio ocupó un $2 \%$ del tiempo total, la mayor parte frente a Coereba flaveola, una especie nectarívora introducida que parece constituir un importante competidor de A. amazilia. El uso de las distintas especies de flores no se relaciona con su abundancia $\left(\chi_{9}^{2}=1546, \mathrm{p}<0.0001\right)$, siendo Justicia brandegeana y Salvia splendens de flores rojas seleccionadas e Impatiens balsamina rechazada. La gran cantidad de tiempo que pasa en las perchas las convierte en un elemento importante del hábitat. Las perchas seleccionadas se encuentran típicamente en árboles, cercanas a las flores que visita y, se sitúan en posición baja y central rodeadas de baja densidad de follaje, probablemente para minimizar la pérdida de calor.

Palabras clave: distribución de tiempo, jardines urbanos, uso del hábitat, Amazilia amazilia.

\section{REFERENCES}

Adams, P.A., G.J. Robertson \& I.L. Jones. 2000. Timeactivity budgets of Harlequin ducks molting in the Gannet Islands, Labrador. Condor 102: 703-708.

Clergeau, P., J.P.L. Savard, G. Mennechez \& G. Falardeau. 1998. Bird abundance and diversity along an urbanrural gradient: A comparative study between two cities on different continents. Condor 100: 413-425.

Corbet, S.A., J. Bee, K. Dasmahapatra, S. Gale, E. Gorringe, B. La Ferla, T. Moorhouse, A. Trevail, Y. Van Bergen \& M. Vorontsova. 2001. Native or exotic? Double or single? Evaluating plants for pollinator-friendly gardens. Ann. Bot-London, 87: 219-232.

Ewald, P.W. \& F.L. Carpenter. 1978. Territorial responses to energy manipulations in the Anna Hummingbird. Oecologia 31: 277-292.

Font, E. \& M.J. Ferrer. 1995. Gallotia galloti (Canary Islands Lizard) nectar feeding. Herp. Rev. 26: 35-36.

González, O. 1998. Coereba flaveola, un ave nueva en el ecosistema de los parques de la ciudad de Lima. Ecología 1: 79-83.

Guillén C. \& J. Barrio. 1995. Los Pantanos de Villa y sus aves. Bol. de Lima, 16: 53-58.
Hainsworth F.R. \& L.L. Wolf. 1978. Regulation of metabolism during torpor in "temperate" zone hummingbirds. Auk 95:197-199.

Henderson, J. 1927. The practical value of birds. MacMillan, New York, USA. 342p.

Karasov, W.H., D. Phan, J.M. Diamond \& F.L. Carpenter. 1986. Food passage and intestinal nutrient absorption in hummingbirds. Auk 103: 453-464.

Koepche, M. (ed.) 1964. Las aves del departamento de Lima. Morson, Lima, Peru. 118 p.

Lasiewski, R.C. \& W.R. Dawson. 1967. A re-examination of the relation between standard metabolic rate and body weight in birds. Condor 69: 13-23.

MacArthur, R.H. \& E.R. Pianka. 1966. On optimal use of a patchy environment. Am. Nat. 100: 603-609.

Maeda, T. 1998. Bird communities and habitat relationships in a residential area of Tokyo. J. Yamashina Inst. Ornithol. 30: 83-100.

McWhorter, T.J. \& C. Martínez del Rio. 1999. Food ingestion and water turnover in hummingbirds: How much dietary water is absorbed? J. Exp. Biol. 202: 2851-2858.

Paulus, S.L. 1988. Time-activity budgets of non-breeding Anatidae: a review, p. 135-152. In M.W. Weller (ed.). Waterfowl in winter. Univ. Minnesota, Minneapolis, Minnesota, USA.

Remsen, J.V. \& S. K. Robinson. 1990. A Classification scheme for foraging behavior of birds in terrestrial habitats. Stud. Avian Biol. 13: 144-160.

Sánchez, L.A., A. Picado, M.J. Sommeijer \& E.J. Slaa. 2002. Floral biology, pollination ecology and seed production of the ornamental plant Salvia splendens Sello. J. Hortic. Sci. Biotech. 77: 498-501.

Sazima, M. \& I. Sazima. 1999. The perching bird Coereba flaveola as a co-pollinator of bromeliad flowers in southeastern Brazil. Can. J. Zool. 77: 47-51.

Schoener, T.W. 1971. Theory of feeding strategies. Ann. Rev. Ecol. Syst. 2: 369-404.

Weller, A.A. 2000. Biogeography, geographic variation and habitat preference in the Amazilia Hummingbird, Amazilia amazilia Lesson (Aves: Trochilidae), with notes on the status of Amazilia alticola Gould. J. Ornithol. 141: 93-101.

Wheeler, T. 1980. Experiments in feeding behavior of the Anna hummingbird. Wilson Bull. 92: 53-62.

Wolf, L.L. \& F.R. Hainsworth. 1971. Time and energy budgets of territorial hummingbirds. Ecology 52: 980-988. 